\title{
Efektivitas Penggunaan Bahan Ajar Video Interaktif Hak Asasi Manusia (Viktif HAM) untuk Perkuliahan Hak Asasi Manusia
}

\author{
Ida Putri Rarasati ${ }^{1^{*}}$, Meiwatizal Trihastuti ${ }^{2}$, Muhammad Iqbal Baihaqi ${ }^{3}$ \\ ${ }^{1}$ Universitas Islam Balitar Blitar, Indonesia \\ ${ }^{2}$ STKIP Pasundan Cimahi, Indonesia \\ ${ }^{3}$ Institut Agama Islam Negeri Salatiga, Indonesia
}

Idputri277@gmail.com*

\begin{tabular}{|c|c|}
\hline & Abstract \\
\hline $\begin{array}{c}\text { ARTICLE INFO } \\
\text { Article history: } \\
\text { Received } \\
\text { December 02, } \\
2020 \\
\text { Revised } \\
\text { December 06, } \\
2020 \\
\text { Accepted } \\
\text { December } 21 \text {, } \\
2020\end{array}$ & $\begin{array}{l}\text { This article was to determine the validity, practicality testing and effectiveness of } \\
\text { human rights learning. The method used research and develeopment (RnD) that } \\
\text { aims to develop multimedia Viktif HAM teaching materials, to test the } \\
\text { effectiveness of teaching materials in achieving learning objectives. The results } \\
\text { showed that in the developing Viktif HAM teaching materials, was knowing } \\
\text { potential problems and collecting data, making prototypes of teaching materials, } \\
\text { conducting expert validation and revision, small and large scale field trials. } \\
\text { Based on the results of expert validation, the developed teaching materials are in } \\
\text { the very valid category with an average validation score of } 89.2 \% \text { in all aspects } \\
\text { of assessment. Students as respondents also gave a positive response with a } \\
\text { questionnaire score of } 92.5 \% \text { showing a very valid quality without revision. The } \\
\text { effectiveness of the use of Viktif HAM teaching materials in lectures was } \\
\text { calculated by analyzing the results of pre and post tests using N-Gain showing an } \\
\text { average of } 0.77 \text {. So it can be concluded that Viktif HAM human rights teaching } \\
\text { materials are effectively used for human rights learning. }\end{array}$ \\
\hline
\end{tabular}

Published by

Keywords: Human Rights Learning, Interactive Video, Teaching Materials

Website

Lembaga Penelitian dan Pengabdian Kepada Masyarakat

Institut Agama Islam Negeri Metro

http://e-journal.metrouniv.ac.id/index.php/tapis/index

This is an open access article under the CC BY SA license

https://creativecommons.org/licenses/by-sa/4.0/

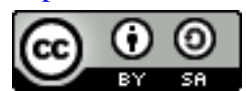

\section{PENDAHULUAN}

Proses pembelajaran di Perguruan Tinggi sebagai upaya mengimplementasikan kurikulum agar mahasiswa dapat mencapai tujuan pembelajaran yang diharapkan menuju pada perubahan tingkah laku baik intelektual, moral maupun sosial agar dapat hidup mandiri sebagai makhluk individu dan sosial. Dalam proses mencapai tujuan tersebut diperlukan interaksi di lingkungan belajar yang telah dirancang oleh dosen. Lingkungan belajar yang diatur meliputi tujuan pembelajaran, bahan pembelajaran, metodologi pembelajaran serta penilaian pembelajaran (Keating \& DeBoor, 2017). Berdasarkan hasil observasi dan wawancara langsung yang dilakukan dengan dosen dan beberapa mahasiswa Program Studi Pendidikan Pancasila dan Kewarganegaraan (PPKN) Universitas Islam Balitar pada perkuliahan Hak Asasi Manusia (HAM) mengidentifikasi bahwa, (1) proses pembelajaran mengacu pada kurikulum Kerangka Kualifikasi Nasional Indonesia (KKNI), namun dalam penerapannya masih kurang maksimal karena belum mengacu pada pembelajaran berbasis teknologi digital, (2) dosen masih cenderung mendominasi perkuliahan dengan menggunakan media penunjang seadanya. Media pembelajaran yang sering digunakan hanya terbatas dengan LCD proyektor yang menyajikan slide powerpoint materi perkuliahan, (3) tugas mandiri dan kelompok yang diberikan dosen hanya terbatas pada kajian literatur saja.

Doi http://doi.org/10.32332/tapis.v4i2.2685

ISSN Print 2579-3233; Online 2580-068X

| Volume 4 Number 2, December 2020, page 202-209 
Bahan ajar sebagai salah satu sarana pembelajaran yang penting untuk digunakan dalam pembelajaran. Bahan ajar terdiri dari materi pembelajaran, metode ajar, batasan materi, dan teknik evaluasi yang didesain secara sistematis untuk mencapai kompetensi (Rizal et al., 2020; Widodo \& Jasmadi, 2013; Magdalena et al., 2020). Bahan atau materi pembelajaran adalah "isi" dari kurikulum, yakni berupa mata pelajaran atau bidang studi dengan topik/subtopik dan rinciannya (Ruhimat, 2011). Di era globalisasi, bahan ajar seperti multimedia, pengembangan bahan ajar layak dijadikan alternatif yang efisien dalam proses belajar (Suhono \& Sari, 2020). Melalui bahan ajar multimedia yang lengkap dengan audio visual sangat membantu dosen dalam menanamkan konsep materi kepada mahasiswa, serta juga memudahkan mahasiswa memahami materi (Prawiradilaga, 2016; Purba et al., 2020). Rusman (2012) menyatakan bahwa bahan ajar audio visual merupakan kombinasi audio dan visual berupa film bersuara, video/televisi pendidikan dan sound slide. Dengan bahan ajar audio visual, kegiatan pembelajaran akan melibatkan pendengaran dan penglihatan sekaligus dalam satu proses. Hal ini akan memusatkan konsentrasi mahasiswa dalam proses belajar sehingga materi lebih mudah dipahami, selain itu media audio visual juga dapat diputar secara berulang-ulang (Abi Hamid et al., 2020; Malik \& Agarwal, 2012). Dengan mengkolaborasikan program-program komputer untuk membuat video interaktif yang dapat membantu dosen dalam mengatasi keterbatasan pedagogi (Mahadewi et al., 2020), sehingga pembelajaran berjalan lebih efektif dan efisien. Dosen dapat fokus mengamati proses dan perkembangan belajar mahasiswanya sekaligus melakukan penelitian pendidikan

Beberapa kajian terdahulu diantaranya Budijono \& Wahyu (2012) yang memfokuskan penggunaan model penelitian tindakan yang berbentuk spiral dari siklus yang satu ke siklus berikutnya. Rujukan lain yang ditulis oleh Malik \& Agarwal (2012) yang berjudul Use of Multimedia as a New Educational Technology Tool - A Study menunjukkan peran penting multimedia dalam proses pembelajaran. Sehingga peran pedagogi dapat dimaksimalkan dan proses pembelajaran dapat ditingkatkan efektivitasnya. Menurut Lasmiyati \& Idris Hatta (2014) bahwa salah satu faktor keberhasilan pembelajaran tergantung pada ketersediaan fasilitas belajar seperti buku pelajaran. Dari beberapa jenis buku pelajaran, modul dapat menjadi salah satu alternatif bahan ajar yang efektif dapat meningkatkan pemahaman konsep dan minat belajar dengan didukung pembaruan sistem pengajaran yang fokus kepada pola pengajaran berprogram dan pengajaran dengan modul. Sasmita, A., \& Fajriyah, K. (2018) berpendapat bahwa penggunaan modul dalam pembelajaran akan maksimal bila ditunjang dengan penerapan model pembelajaran quantum. Hal ini karena situasi pembelajaran dirancang secara detail dengan menciptakan lingkungan belajar yang efektif, nyaman dan menyenangkan. Sehingga peserta didik lebih bebas dalam menemukan pengalaman belajar yang baru. Rimay et al., (2018) juga mengembangkan modul multimedia berbasis TGT. Modul multimedia yang dikembangkan dengan bantuan software Flipbook Maker yang dapat mengubah file dalam bentuk pdf menjadi tampil layaknya buku. Dengan mengkolaborasikan penggunaan modul dengan model pembelajaran TGT dapat memberikan kesempatan kepada peserta didik untuk berkomunikasi dan berinteraksi sosial untuk mencapai tujuan pembelajaran.

Sedangkan menurut Naj'iyah (2019) penggunaan modul interaktif berbasis LCDS (Learning Content Development System) lebih efektif dalam meningkatkan hasil belajar serta dapat menumbuhkan kemampuan berpikir kritis peserta didik. Dengan memanfaatkan kecanggihan teknologi, guru dapat merancang bahan ajar yang dapat menarik perhatian dan memotivasi peserta didik untuk aktif belajar, membuat suasana kelas tidak monoton, melatih belajar mandiri, membantu peserta didik dalam menguasai materi sehingga akan berpengaruh terhadap peningkatan penguasaan konsep. Rini et al., (2018) mengembangkan modul pembelajaran multimedia interaktif berbasis adobe director, sedangkan Anis Mahmudah (2019) pengembangan bahan ajar interaktif lebih efektif dan efisien dengan memanfaatkan program komputer, salah satunya Lectora Inspire. Dengan program komputer tersebut, bahan ajar dapat dirancang sesuai kebutuhan pembelajaran seperti pelatihan on line, presentasi, menyajikan gambar dan video, test serta penilaian pembelajaran.

Sementara, kajian penelitian ini memfokuskan pada pengembangan bahan ajar berbasis multimedia berupa Video Interaktif Hak Asasi Manusia (Viktif HAM), diharapkan dapat 
menambah ketersediaan bahan ajar dalam perkuliahan dan mampu meningkatkan efektivitas pembelajaran mandiri. Melalui penggunaan bahan ajar multimedia berupa video ini mata kuliah Hak Asasi Manusia (HAM) diharapkan mampu meningkatkan pemahaman konsep dan prinsip HAM sehingga kesadaran dalam penegakan HAM dapat diwujudkan. Pembelajaran dengan berbasis multimedia sangat membantu mahasiswa dalam memahami materi perkuliahan yang kompleks dan multi disiplin ilmu. Multimedia khususnya video tidak berfungsi sebagai penghibur saja, melainkan dapat dimaksimalkan sebagai media pendidikan yang dikemas menarik sehingga memudahkan proses belajar. Penggunaan VIKTIF HAM ini juga dapat dokolaborasikan dengan metode pembelajaran sesuai dengan kondisi dan kebutuhan belajar di kelas.

\section{METODE}

Penelitian ini menggunakan metode penelitian dan pengembangan (Research and Development) (Zakariah, Afriani, \& Zakariah, 2020; Arikunto, 2017). Produk yang dikembangkan dalam penelitian ini berupa bahan ajar multimedia video interaktif yang membahas tentang hak asasi manusia. Adapun prosedur pengembangan menurut Arikunto (2017) yang diadaptasi dalam penelitian ini mengikuti sepuluh tahapan diantaranya: 1) mengetahui potensi dan masalah dengan mengumpulkan informasi termasuk kajian literatur, observasi pembelajaran, dan membuat kerangka kerja penelitian, 2) mengumpulkan data, 3) membuat rancangan desain produk, 4) memvalidasikan desain produk kepada ahli desain, ahli materi dan ahli bahasa 5) melakukan revisi desain produk sesuai saran dari validator, 6) uji coba produk terbatas, 7) revisi produk, 8) uji coba produk skala besar, 9) revisi produk, 10) menghasilkan Viktif HAM yang layak digunakan untuk perkuliahan HAM di Program Studi Pendidikan Pancasila dan Kewarganegaraan. Namun pada penelitian ini, peneliti membatasi langkah penelitian disesuaikan dengan kebutuhan.

Analisis data kualitatif dalam penelitian ini dilakukan berdasarkan hasil observasi pembelajaran dan wawancara dengan dosen dan mahasiswa. Wawancara dengan dosen pengampu mata kuliah bertujuan untuk menggali informasi tentang proses pembelajaran serta minimnya penggunaan sumber belajar khususnya bahan ajar yang memanfaatkan teknologi informasi. Wawancara juga dilakukan dengan beberapa mahasiswa yang bertujuan untuk menggali informasi sejauh mana mahasiswa mengikuti proses pembelajaran dengan memanfaatkan sumber belajar yang ada, juga mengukur pemahaman mahasiswa selama mengikuti perkuliahan. Selanjutnya hasil wawancara tersebut diambil kesimpulan untuk menentukan potensi dan masalah penelitian. Sedangkan analisis data kualitatif diolah berdasarkan hasil angket validasi, angket respon dosen dan mahasiswa serta instrumen tes (pre dan post test). Teknik analisis data angket validasi menggunakan skala likert, sedangkan angket respon dosen dan mahasiswa menggunakan skala gutman. Instrumen tes (pre dan post test) akan dianalisis menggunakan rumus $\mathrm{N}$-gain untuk mengetahui efektivitasnya.

\section{HASIL DAN PEMBAHASAN}

Pada penelitian pengembangan ini menghasilkan bahan ajar multimedia berupa video interaktif untuk perkuliahan HAM yang dilengkapi dengan pembahasan materi berupa tayangan audio visual. Berdasarkan identifikasi awal ditemukan potensi dan masalah yang terdapat pada perkulihan HAM di Program Studi PPKN Universitas Islam Balitar. Tahap observasi dilakukan melalui survei proses perkuliahan dan pemberian angket kepada dosen dan mahasiswa. Berdasarkan hasil observasi tersebut diperoleh informasi bahwa minimnya ketersediaan bahan ajar untuk perkuliahan HAM, mahasiswa belum terbiasa melakukan kegiatan analisis, menalar dan mencipta. Selama perkuliahan belum memaksimalkan penggunaan teknologi informasi.

Hasil observasi terhadap dosen menunjukkan bahwa selama ini pembelajaran sudah sesuai dengan rencana perkuliahan semester, namun hasilnya belum maksimal karena kurangnya persiapan dan banyak mahasiswa tidak antusias mengikuti perkuliahan. Selama perkuliahan, dosen sudah sering menggunakan strategi pembelajaran tertentu dan menggunakan metode perkuliahan yang bervariatif namun hal itu justru menghambat mahasiswa memahami materi karena dianggap terlalu rumit dan tidak menarik. Rendahnya minat mahasiswa untuk 
membaca juga menjadi faktor penghambat dalam pemahaman materi, hal ini tampak pada hasil tugas mahasiswa cenderung sering mengutip/merujuk artikel dari internet yang belum jelas relevansinya.

Viktif HAM didesain berdasarkan rencana perkuliahan semester yang dapat digunakan untuk 16 kali pertemuan perkulihan. Ada beberapa bagian dalam materi video yang diambil secara langsung dengan melibatkan proses shooting. Adapun susunan dalam video tersebut terdiri dari lima topik utama dengan tiap-tiap topik pembahasan terdapat beberapa kegiatan perkuliahan yang meliputi: kajian literatur, tugas mandiri, tugas kelompok dan proyek. Tugas mandiri yang diberikan berupa memberikan pendapat/tanggapan pribadi terhadap isu publik, membuat peta konsep, dan membuat paper. Tugas kelompok meliputi kegiatan diskusi, jajak pendapat, presentasi, melakukan analisis kasus pelanggaran HAM, dan demonstrasi. Sedangkan tugas proyek adalah membuat komik interaktif bersuara tentang kronologi kasus pelanggaran HAM, dan mendemonstrasikan topik HAM tertentu kemudian merekamnya menjadi sebuah video inspiratif yang dapat digunakan untuk menunjang perkuliahan. Pemaparan materi dalam video interaktif tersebut disertai contoh implementasi berupa gambar bergerak sehingga materi dikemas secara menarik dan dapat diputar secara berulang-ulang baik dalam situasi perkuliahan maupun di luar perkuliahan. Selain itu juga berisi kegiatan ice breaking yang berfungsi untuk membangkitkan kembali semangat belajar melalui: tepuk kreasi HAM, senam kesadaran HAM, dan puisi tentang HAM yang berjudul "Demokrasi Bukan Sekedar Imaji". Dengan adanya kegiatan yang bervariatif dalam video interaktif ini diharapkan selama perkulihan mahasiswa tidak merasa kesulitan belajar karena melibatkan beberapa ketrampilan khusus yang dapat mengasah kreativitas mahasiswa. Tahapan penelitian selanjutnya, prototype awal VIKTIF HAM yang telah dibuat akan divalidasi oleh para ahli bahasa, ahli materi, dan ahli desain. Berikut hasil validasi ahli yang pertama:

Tabel 1. Hasil Validasi Ahli yang Pertama

\begin{tabular}{|c|c|c|c|}
\hline Validator Ahli & $\begin{array}{c}\text { Rata-Rata } \\
\text { Skor (\%) }\end{array}$ & Kategori & \multicolumn{1}{|c|}{ Kritik/Saran } \\
\hline Ahli Bahasa & 87.8 & $\begin{array}{c}\text { Sangat Valid } \\
\text { tanpa revisi }\end{array}$ & - \\
\hline Ahli Materi & 73.8 & $\begin{array}{c}\text { Valid } \\
\text { dengan revisi }\end{array}$ & $\begin{array}{l}\text { Tambahkan kuis interaktif pada video } \\
\text { setiap pertengahan pembahasan materi }\end{array}$ \\
\hline Ahli Desain & 82.7 & $\begin{array}{l}\text { Sangat Valid } \\
\text { dengan revisi }\end{array}$ & $\begin{array}{l}\text { Video sebaiknya disimpan dalam } \\
\text { format folder tiap modul sehingga } \\
\text { memudahkan pengguna sesuai } \\
\text { kebutuhan }\end{array}$ \\
\hline
\end{tabular}

Berdasarkan hasil validasi ahli dengan memperhatikan masukan dan saran tersebut dilakukan revisi produk terutama pada video interaktif dengan menyisipkan beberapa kuis (pertanyaan yang dijawab secara cepat) pada setiap materi yang disajikan. Dalam tiap-tiap materi setidaknya ada tiga sampai lima pertanyaan yang dapat dijawab mahasiswa secara cepat. Selain itu untuk satu topik pembahasan materi, file video disimpan dalam satu keping DVD sehingga memudahkan mahasiswa ketika belajar. File dalam tiap-tiap keping DVD disusun dalam format folder dengan nama folder judul materi HAM. Prototype Viktif HAM yang sudah direvisi siap untuk divalidasikan kembali kepada para ahli. Berikut hasil validasi yang kedua :

Tabel 2. Hasil Validasi Ahli yang Kedua

\begin{tabular}{|c|c|c|c|}
\hline Validator Ahli & $\begin{array}{c}\text { Rata-Rata } \\
\text { Skor (\%) }\end{array}$ & Kategori & Kritik/Saran \\
\hline Ahli Materi & 89.7 & Sangat Valid tanpa revisi & - \\
\hline Ahli Media & 90.2 & Sangat Valid tanpa revisi & - \\
\hline
\end{tabular}


Berdasarkan hasil validasi di atas, VIKTIF HAM yang dikembangkan ini sudah dinyatakan sangat valid tanpa revisi, sehingga layak digunakan untuk uji coba kelompok kecil. Penilaian oleh dosen di Program Studi PPKN juga manjadi bahan evaluasi peneliti sebagai pertimbangan bahwa bahan ajar Viktif HAM ini dapat digunakan untuk perkuliahan HAM. Dosen memberikan penilaian bahwa pembahasan materi dalam bahan ajar ini sudah termasuk lengkap dan menyeluruh, kegiatan individu dan kelompok yang disusun dalam tiap-tiap topik pembahasan materi juga bervariatif, tugas proyek juga mempertimbangkan penggunaan teknologi informasi yang sesuai dengan tujuan kurikulum KKNI. Konsep bahan ajar tayangan interaktif berupa video dapat meningkatkan minat baca mahasiswa, serta melatih mahasiswa belajar mandiri mengikuti setiap petunjuk dalam tayangan tersebut. Sehingga ketrampilan mandiri dapat diasah seiring dengan proses belajar yang dijalani mahasiswa.

Tahap penelitian selanjutnya adalah uji coba lapangan baik dalam skala kecil maupun skala besar. Tujuan uji coba lapangan ini untuk mengetahui kepraktisan dan efektivitas penggunaan Viktif HAM untuk perkuliahan HAM. Aspek pengujian kepraktisan meliputi kemudahan penggunaan bahan ajar, efisiensi waktu belajar, pengalaman belajar, dan manfaat yang diperoleh mahasiswa. Sedangkan untuk menguji efektivitas penggunaan bahan ajar Viktif HAM diukur dengan menganalisis hasil tes (pre dan post test) yang dibandingkan dan dianalisis menggunakan rumus $\mathrm{N}$-gain.

Hasil uji lapangan skala kecil menunjukkan hasil rata-rata skor angket yang diisi oleh reponden mencapai $87.5 \%$ menunjukkan kualitas sangat valid tanpa revisi secara keseluruhan. Banyak responden yang memberikan komentar dan respon yang baik selama belajar dengan menggunakan Viktif HAM. Bahkan mahasiswa merasa lebih mudah memahami materi karena diberikan penjelasan video yang menarik dan dapat diputar secara berulang. Saran dari mahasiswa pada tugas proyek membuat komik bersuara dibutuhkan materi tutorial karena kebanyakan mahasiswa belum memiliki ketrampilan pemrograman komputer dan desain grafis yang memadai. Hal ini meningkatkan keingintahuan mahasiswa untuk belajar memahami pemrograman komputer secara mandiri (outodidak). Hasil uji coba lapangan skala besar menunjukkan hasil rata-rata skor angket responden mencapai $92.5 \%$ menunjukkan kualitas sangat valid tanpa revisi secara keseluruhan. Banyak responden yang memberikan komentar dan respon positif selama belajar dengan Viktif HAM dan merasa mendapatkan pengalaman belajar yang baru dalam setiap kegiatan belajar. Selanjutnya untuk melihat efektivitas penggunaan bahan ajar Viktif HAM dalam proses pembelajaran, dilakukan analisis hasil tes (pre dan post test) sebagai berikut:

Tabel 3. Perhitungan N-gain Hasil Test (Pre dan Post Test)

\begin{tabular}{|c|c|c|c|c|c|c|}
\hline Responden & $\begin{array}{c}\text { Pre } \\
\text { Test }\end{array}$ & $\begin{array}{c}\text { Post } \\
\text { Test }\end{array}$ & $\begin{array}{c}\text { N- } \\
\text { gain }\end{array}$ & $\begin{array}{c}\text { Nilai } \\
\text { Max }\end{array}$ & Rentang & Kriteria \\
\hline 1 & 60 & 95 & 0.88 & 100 & $\mathrm{~g}>0.7$ & Tinggi \\
\hline 2 & 55 & 85 & 0.67 & 100 & $0.3 \leq \mathrm{g} \leq 0.7$ & Sedang \\
\hline 3 & 65 & 90 & 0.71 & 100 & $\mathrm{~g}>0.7$ & Tinggi \\
\hline 4 & 60 & 90 & 0.75 & 100 & $\mathrm{~g}>0.7$ & Tinggi \\
\hline 5 & 50 & 95 & 0.90 & 100 & $\mathrm{~g}>0.7$ & Tinggi \\
\hline 6 & 45 & 85 & 0.73 & 100 & $\mathrm{~g}>0.7$ & Tinggi \\
\hline 7 & 50 & 85 & 0.70 & 100 & $\mathrm{~g}>0.7$ & Tinggi \\
\hline 8 & 70 & 100 & 1.00 & 100 & $\mathrm{~g}>0.7$ & Tinggi \\
\hline 9 & 55 & 85 & 0.67 & 100 & $0.3 \leq \mathrm{g} \leq 0.7$ & Sedang \\
\hline 10 & 60 & 85 & 0.63 & 100 & $0.3 \leq \mathrm{g} \leq 0.7$ & Sedang \\
\hline 11 & 55 & 90 & 0.78 & 100 & $\mathrm{~g}>0.7$ & Tinggi \\
\hline 12 & 50 & 85 & 0.70 & 100 & $\mathrm{~g}>0.7$ & Tinggi \\
\hline 13 & 45 & 80 & 0.64 & 100 & $0.3 \leq \mathrm{g} \leq 0.7$ & Sedang \\
\hline 14 & 50 & 85 & 0.70 & 100 & $\mathrm{~g}>0.7$ & Tinggi \\
\hline
\end{tabular}




\begin{tabular}{|c|c|c|c|c|c|c|}
15 & 60 & 90 & 0.75 & 100 & $\mathrm{~g}>0.7$ & Tinggi \\
\hline 16 & 55 & 95 & 0.89 & 100 & $\mathrm{~g}>0.7$ & Tinggi \\
\hline 17 & 45 & 85 & 0.73 & 100 & $\mathrm{~g}>0.7$ & Tinggi \\
\hline 18 & 55 & 90 & 0.78 & 100 & $\mathrm{~g}>0.7$ & Tinggi \\
\hline 19 & 50 & 95 & 0.90 & 100 & $\mathrm{~g}>0.7$ & Tinggi \\
\hline 20 & 70 & 100 & 1.00 & 100 & $\mathrm{~g}>0.7$ & Tinggi \\
\hline 21 & 65 & 95 & 0.86 & 100 & $\mathrm{~g}>0.7$ & Tinggi \\
\hline 22 & 60 & 95 & 0.88 & 100 & $\mathrm{~g}>0.7$ & Tinggi \\
\hline 23 & 55 & 85 & 0.67 & 100 & $0.3 \leq \mathrm{g} \leq 0.7$ & Sedang \\
\hline 24 & 60 & 90 & 0.75 & 100 & $\mathrm{~g}>0.7$ & Tinggi \\
\hline 25 & 65 & 90 & 0.71 & 100 & $\mathrm{~g}>0.7$ & Tinggi \\
\hline Jumlah & $\mathbf{1 4 1 0}$ & $\mathbf{2 2 4 5}$ & $\mathbf{1 9 . 3 4 6}$ & $\mathbf{2 5 0 0}$ & & \\
\hline Rata-rata & $\mathbf{5 6 . 4}$ & $\mathbf{8 9 . 8}$ & $\mathbf{0 . 7 7 3 8}$ & $\mathbf{1 0 0}$ & $\mathbf{g}>\mathbf{0 . 7}$ & Efektif \\
\hline
\end{tabular}

Berdasarkan tabel hasil perhitungan N-Gain hasil test responden di atas menunjukkan rata-rata sebesar 0.77 yang dapat disimpulkan bahwa bahan ajar Viktif HAM efektif digunakan untuk pembelajaran HAM di Program Studi PPKN.

Temuan dalam penelitian ini berupa studi meta sintesis dari konsep pembelajaran dengan konsep pengembangan bahan ajar modul dan penggunaan sarana multimedia sehingga dapat mewujudkan konteks pembelajaran dengan memanfaatkan teknologi informasi di era revolusi industri 4.0. Dua konsep yang melahirkan meta sintesis tersebut memiliki relevansi sebagai berikut: (1) sebagai bentuk nyata perkembangan teknologi informasi untuk menunjang proses pembelajaran dengan menggunakan beberapa program dan aplikasi komputer, (2) melahirkan budaya belajar mandiri, (3) pembelajaran kontekstual dengan disajikan materi sesuai perkembangan jaman yang membahas isu-isu publik baik dalam ruang lingkup nasional maupun internasional, (4) pembelajaran otentik dan multidisipliner mengikuti perkembangan ilmu pengetahuan dan teknologi, (5) pembelajaran kolaboratif sehingga menumbuhkan kerjasama dalam pembelajaran.

Dalam penelitian sebelumnya, Lasmiyati \& Idris (2014), Amara \& Khusnul (2018), dan juga Maulina, J., \& Pohan, L. A. (2018) mengembangkan bahan ajar berupa modul konfensional dan mengkolaborasikannya dengan model pembelajaran tertentu. Ramadhanty et al., (2019) dan Sefriani, \& Wijaya (2018) telah mengembangkan bahan ajar modul multimedia dengan memggunakan aplikasi tertentu, tetapi tampilannya masih berupa slideshow dilengkapi dengan beberapa animasi dan dubbing suara. Sedangkan dalam penelitian ini lebih mengarah pada pembuatan bahan ajar berupa modul berbasis multimedia berupa video dengan menampilkan gambar bergerak dilengkapi dengan dubbing suara karena pada proses pembuatannya elibatkan proses shooting secara langsung sehingga materi pembelajaran tersaji secara kontekstual serta membahas isu-isu publik yang aktual lebih memudahkan peserta didik memahami materi.

Hasil penelitian ini memiliki implikasi bagi para praktisi pendidikan untuk mengembangkan bahan ajar berbasis multimedia dengan pembahasan materi yang dilengkapi aktivitas belajar bervariatif untuk memenuhi tuntutan kualitas pembelajaran di era revolusi industri 4.0. Para praktisi juga dapat mengembangkan dan menerapkan pembelajaran berbasis modul multimedia dalam perkuliahan sesuai kebutuhan belajar sehingga pembelajaran dapat terencana dengan baik, masalah serta isu-isu publik dapat dijadikan bahan kajian perkuliahan, kegiatan perkuliahan dapat berjalan sesuai jadwal, dan proses evaluasi pembelajaran dilakukan dengan mudah dan terukur. Bahan Ajar Viktif HAM ini memiliki aspek keterbaruan diantaranya self instructional, video ini dapat digunakan oleh mahasiswa untuk belajar secara mandiri meski tanpa pendampingan dosen, karena dirancang dengan menyajikan konsep teori dengan bahasa yang mudah dipahami serta memberikan contoh-contoh aplikasi teori yang kontekstual berupa gambar video. Aspek self contained yang menyajikan konsep materi secara menyeluruh, utuh dan runtut dari tiap-tiap unit kompetensi yang diharapkan. Aspek adaptive, Viktif HAM dapat 
menyesuaikan perkembangan ilmu pengetahuan dan teknologi serta berisikan informasi yang berisi peristiwa tentang HAM yang terbarukan dalam ruang lingkup nasional maupun internasional. Aspek user friendly, Viktif HAM sangat memudahkan mahasiswa untuk belajar karena dapat diakses dengan mudah serta dapat digunakan secara berulang-ulang dalam jangka waktu lama. Berdasarkan beberapa aspek tersebut diharapkan dapat meningkatkan efektivitas perkuliahan HAM

\section{KESIMPULAN}

Berdasarkan hasil pengembangan dan pembahasan di atas dapat disimpulkan bahwa tingkat kevalidan bahan ajar Viktif HAM telah divalidasi oleh ahli materi, ahli desain dan ahli bahasa dengan memperhatikan aspek kesesuaian materi, soal evaluasi, desain/tampilan, dan bahasa. Penilaian oleh dosen ahli menunjukkan bahwa Viktif HAM layak digunakan untuk pembelajaran HAM. Uji coba lapangan skala kecil dan besar terkait kepraktisan penggunaan Viktif HAM dengan respondennya adalah mahasiswa Program Studi PPKN Universitas Islam Balitar menunjukkan bahwa bahan ajar tersebut mudah digunakan karena dapat membantu mahasiswa memahami materi, waktu belajar lebih efisien, mampu mengekplorasi pengalaman belajar karena menyajikan kegiatan belajar yang bervariatif. Saran dan komentar dari responden menunjukkan respon yang baik terhadap penggunaan bahan ajar Viktif HAM. Pengujian efektivitas penggunaan bahan ajar Viktif HAM dalam proses pembelajaran juga menunjukkan hasil yang efektif berdasarkan analisis data $\mathrm{N}-$ Gain skor pre dan post test yang membuktikan adanya peningkatan skor.

\section{UCAPAN TERIMAKASIH}

Hasil penelitian yang termuat dalam jurnal ilmiah ini merupakan output dari dana hibah penelitian dari Universitas Islam Balitar dengan surat keputusan Nomor 7/E/KPT/2019 Tanggal 7 Februari 2019 dan perjanjan/kontrak Nomor 054/SP2H/LT/MONO/L7/2019 Tanggal 26 Maret 2019 dan 015/LPPM/UNISBA/III/2019 Tanggal 28 Maret 2019.

\section{PERNYATAAN KONTRIBUSI PENELITI}

Penelitian ini dilakukan oleh Ida Putri Rarasati (IPR) dan Muhammad Iqbal Baihaqi (MIB). Meiwatizal Trihastuti (TS) membantu menyelesaikan proses revisi dalam penyempurnaan naskah artikel.

\section{DAFTAR PUSTAKA}

Arikunto, S. (2017). Prosedur Penelitian Suatu Pendekatan Praktik, Jakarta: PT. Asdi Mahasatya. Goole Scholar

Abi Hamid, M., Ramadhani, R., Masrul, M., Juliana, J., Safitri, M., Munsarif, M., ... \& Simarmata, J. (2020). Media Pembelajaran. Yayasan Kita Menulis. Google Scholar

Budijono, A. P., \& Kurniawan, W. D. (2012). Enerapan Modul Berbasis Komputer Interaktif untuk Meningkatkan Kualitas Proses dan Hasil Pembelajaran pada Mata Kuliah Pneumatik dan Hidraulik. Jurnal Pendidikan Teknologi dan Kejuruan, 21(2). Google Scholar

Keating, S. B., \& DeBoor, S. S. (Eds.). (2017). Curriculum development and evaluation in nursing education. Springer Publishing Company. Google Scholar

Lasmiyati, L., \& Harta, I. (2014). Pengembangan Modul Pembelajaran untuk Meningkatkan Pemahaman Konsep dan Minat SMP. Pythagoras: Jurnal Pendidikan Matematika, 9(2), 161-174. Google Scholar

Maulina, J., \& Pohan, L. A. (2018). Pengembangan modul multimedia berbasis tgt terhadap hasil belajar siswa pada materi peran ilmu kimia dalam kehidupan di man 4 medan. cheds: Journal of Chemistry, Education, and Science, 2(2), 22-30. Google Scholar

Mahadewi, N. K. N., Ardana, I. M., \& Mertasari, N. M. S. (2020). Kemampuan Komunikasi Matematis Melalui Model Reciprocal Teaching Berbantuan Media Interaktif. JNPM (Jurnal Nasional Pendidikan Matematika), 4(2), 338-350. http://dx.doi.org/10.33603/jnpm.v4i2.3606 
Magdalena, I., Sundari, T., Nurkamilah, S., Nasrullah, N., \& Amalia, D. A. (2020). Analisis Bahan Ajar. NUSANTARA, 2(2), 311-326. https://doi.org/10.36088/nusantara.v2i2.828

Mahmudah, A., \& Pustikaningsih, A. (2019). Pengembangan media pembelajaran interaktif berbasis lectora inspire pada materi jurnal penyesuaian untuk siswa kelas $\mathrm{x}$ akuntansi dan keuangan lembaga smk negeri 1 tempel tahun ajaran 2018/2019. Jurnal Pendidikan Akuntansi Indonesia, 17(1), 97-111. https://doi.org/10.21831/jpai.v17i1.26515

Malik, S., \& Agarwal, A. (2012). Use of multimedia as a new educational technology tool-A study. International Journal of Information and Education Technology, 2(5), 468. Google Scholar

Putri, R. M., Risdianto, E., \& Rohadi, N. (2019). Pengembangan Media Pembelajaran Interaktif dengan Menggunakan Adobe Captivate Pada Materi Gerak Harmonik Sederhana. Jurnal Kumparan Fisika, 2(2), 113-120. Google Scholar

Purwanto. 2014. Evaluasi Hasil Belajar. Yogyakarta: Pustaka Pelajar

Prawiradilaga, D. S. (2016). Mozaik Teknologi Pendidikan: E-Learning. Kencana. Google Scholar

Purba, R. A., Tamrin, A. F., Bachtiar, E., Makbul, R., Rofiki, I., Metanfanuan, T., ... \& Ardiana, D. P. Y. (2020). Teknologi Pendidikan. Yayasan Kita Menulis. Google Scholar

Rizal, R., Misnasanti, M., Shaddiq, S., Ramdhani, R., \& Wagiono, F. (2020). Learning Media in Indonesian Higher Education in Industry 4.0: Case Study. International Journal on Advanced Science, Education, and Religion, 3(3), 127-134. https://doi.org/10.33648/ijoaser.v3i3.62

Sasmita, A., \& Fajriyah, K. (2018). Pengembangan modul berbasis quantum learning tema ekosistem untuk kelas V Sekolah Dasar. Refleksi Edukatika: Jurnal Ilmiah Kependidikan, 8(2). https://doi.org/10.24176/re.v8i2.2355

Sefriani, R., \& Wijaya, I. (2018). Modul Pembelajaran Multimedia Interaktif Berbasis Adobe Director Pada Mata Pelajaran Sistem Operasi Sekolah Menengah Kejuruan. INTECOMS: Journal of Information Technology and Computer Science, 1(1), 60-71. https://doi.org/10.31539/intecoms.v1i1.124

Suhono, S., \& Sari, D. A. (2020). Developing Students' Worksheet Based Educational Comic for Eleventh Grade of Vocational High School Agriculture. Anglophile Journal, 1(1), 2940. Google Scholar

Wajong, A. D., Ridwan, R., \& Sangi, N. (2020). Efektivitas Penggunaan Pembelajaran Daring Edmodo Berbantuan Quizstar untuk Meningkatkan Hasil Belajar Mahasiswa. Attractive: Innovative Education Journal, 2(3), 49-60. Google Scholar

Widodo, C. dan Jasmadi.(2008). Buku Panduan Menyusun Bahan Ajar. Jakarta: PT Elex Media Komputindo. Google Scholar

Zakariah, M. A., Afriani, V., \& Zakariah, K. M. (2020). Metodologi penelitian kualitatif, kuantitatif, action research, research and development ( $r n d)$. Yayasan Pondok Pesantren Al Mawaddah Warrahmah Kolaka. Google Scholar

Copyright Holder :

(C) Rarasati I., Trihastuti M., \& Baihaqi M. (2020).

First Publication Right :

(C) Tapis : Jurnal Penelitian Ilmiah

This article is under:

CC BY SA 